\title{
EFFET OF AQUEOUS AND ALCOHOLIC VITEX EXTRACTS ON REPRODUCTIVE AND PRODUCTIVE PERFORMANCE OF DOE RABBITS
}

\author{
Fatma T.F. Abd- El Ghany ${ }^{\mathbf{1}}$; Walaa H. Khalifa ${ }^{2}$ and A.M.M. Saidahmed ${ }^{\mathbf{1}}$ \\ ${ }^{1}$ Animal Production Research Institute, Agricultural Research Center, Dokki, Giza, Egypt. \\ 2 Animal Production Department, National Research Centre, Cairo, Egypt
}

(Received 25/5/2017, accepted 5/7/2017)

\section{SUMMARY}

\begin{abstract}
$\mathrm{T}$ This study was designed to investigate the effect of feeding vitex (Vitex agnus-castus) extracts on productive and reproductive performance of doe rabbits. Fifty New Zealand white does, 7 months old were divided into 5 treatment groups (10 does per group). The first group was fed diet without vitex leaves extract. The second and third were fed diets supplemented with two doses of the aquatic extract (5or $7.5 \mathrm{~g} / \mathrm{kg}$ of diet, respectively). Fourth and fifth groups fed diets supplemented with two doses of the alcoholic extract (5or7.5g / kg of diet, respectively). The studied traits were conception rate, litter size, litter weight at both birth and weaning, pre-weaning mortality and milk yield for three parities. The inclusion of vitex extract affected conception rate, litter size at birth $(P<0.05)$ and weaning $(P<0.05)$, as well as milk yield $(P<0.05)$. However, it tended to increase the kit milk intake in most lactation periods $(P<0.05)$ leading to increase in individual kit weight at weaning $(P<0.05)$, and by using a vitex extract the blood cholesterol levels were reduced. The present results indicate an increase of net revenue for rabbits fed on diets contained extract of vitex leaves at all levels compared to those in control diet. In conclusion, supplementation of vitex leaves extract in the rabbit diet of does can improve their productive and reproductive performance.
\end{abstract}

Keywords: vitex extract, doe rabbits, litter size ,mortality rate, milk yield, economical evaluation.

\section{INTRODUCTION}

Rabbits are the most promising domestic livestock species providing people with a relatively inexpensive source of meat. It has many advantages including high reproductive rates, rapid growth, using of non-competitive feeds, simple housing and requirements (Cheeke, 1987). Moreover, it needs some additives to improve their reproductive process. Vitex agnus-castus, also called vitex, chaste tree is a small shrub or tree up to $6 \mathrm{ft}$. tall, is native to the Mediterranean and western Asia, in Egypt it cultivates in several area especially, in gardens. It is now cultivated all over the World (Upton, 2001). Vitex or chestberry is one of the verbenaceae family comeback to (order Lamiales, class Magnoliopsida, and division magnoliophyta). It can be grown as a large, deciduous, multistemmed shrub with small and narrow leaves, green on top. It contains a mixture of iridoids and flavonoids, the leaves and flowers found to be similar in chemical structure to human sex hormones (Milewicz et al., 1993; Odenthal, 1998; Lucks et al., 2002 and Mustafa, 2007) and also labdanditerpenoids, rolundifuran, vitexilactone which have high binding affinity to dopamine receptors (Hoberg et al., 1999 and Hoberg et al., 2000). In addition flavonoids may have antiviral and antioxidant effect and positive effect on the heart blood vessels (Brenda, 2005). Also, vitex works by regulating and supporting the pituitary gland, which is considered the master gland for hormone production which support the body's natural progesterone and luteinizing hormone production and to stimulate the flow of milk (Hobbs, 1991 and Meyer, 1993). Moreover vitex has been used for hundreds of years to regulate the function of the reproductive organs in women (Christie and Walker, 1998). It is thought to exhibit a normalizing or balancing effect on reproductive hormone production, and to increase luteinizing hormone (LH) levels without affecting follicle stimulating hormone (FSH) (Schellenberg, 2001). In addition to that James et al. (2011) suggested that the use of aqueous extract of vitex and its combination possess antidiabetic and antioxidant activity in rats, could exert a beneficial action against the disease associated with free-radicals complications. Also, Hayder et al. (2014) indicated that the median acute toxicity value $\left(\mathrm{LD}_{50}\right)$ of vitex leaves methanol extract was found to be $17.21 \mathrm{~g} / \mathrm{kg}$ body weight in rats and the extract showed no significantly of toxicity at $5 \mathrm{~g} / \mathrm{kg}$ of the vitex methanol extract concentration. The effect of alcoholic extract of Vitex agnus-castus 


\section{Abd El Ghany et al.}

was examined for its effect on some blood parameters in mice with two doses (6 mg and $12 \mathrm{mg} / \mathrm{mouse}$ ), results showed a significant decrease in total serum protein, total serum cholesterol with both doses in comparison to the control group (Mustafa, 2007).

The aim of this study is to investigate the potential effect of vitex aqueous or alcoholic extracts on productive and reproductive performance of rabbit does with doses.

\section{MATERIALS AND METHODS}

Farm work was conducted at farm belong to Ismael Radwan Farm, Sahl- Elhosainya, Sharqia Governorate, Egypt. The lab work was conducted at Animal Production Department, National Research Centre and Agricultural Research Station, Animal Production Research Institute, Agricultural Research Center, By-product Department, Ministry of Agriculture, Egypt.

\section{Vitex extracts preparation}

The vitex leaves were rinsed with tap water, dried in the dark for 5 days, and then ground to a powder using an electric blender. One hundred grams was placed in $900 \mathrm{ml}$ of $80 \%$ ethanol for four to five days in a laboratory glass container $(1 \mathrm{~L})$ with daily stirring. Afterward, the mixture was filtered through filter paper (Whatman No. 1). The filtrate was evaporated at $40^{\circ} \mathrm{C}$ and the percentage yield of vitex extract powder was obtained for alcoholic extract. For aqueous extract the same method followed without using $80 \%$ ethanol, but used distillated water. Samples of aqueous and alcoholic before evaporating stored in a refrigerator at $4^{\circ} \mathrm{C}$, until making phytochemical screening using methods of Harbone (1973) and Trease and Evans (1983) were used to identify the phytochemicals in the extracts: alkaloids, saponins, tannins, anthraquinones, flavonoids, terpenoids and cardiac glycosides.

\section{Experimental protocol}

A total of fifty does (7 months old) of New Zealand White breed were used in this study for four months. The rabbits were divided to five groups (10 in each group). Two groups were fed diets treated with aqueous extract of vitex powder leaves $(5$ or $7.5 \mathrm{~g} / \mathrm{kg}$ of diet), other two groups were fed diets treated with ethanolic extract of vitex leaves ( 5 or $7.5 \mathrm{~g} / \mathrm{kg}$ of diet) as powder and one group as control group. All experimental animals were apparently healthy and were kept under the same managerial, hygienic and environmental conditions throughout the experimental period. Does were individually housed in galvanized wire batteries provided with feeders and automatic stainless steel nipples for supplying each cage with a clean fresh water all the time. The does' batteries were also provided with nest box measuring $40 \times 30 \times 30 \mathrm{~cm}$ for parturition and rearing of the bunnies. All batteries were located in an open rabbitry and exposed to natural environmental temperature and photoperiod and ventilated by windows and exhausted fans. Ceiling electric fans were also used when needed. Rabbit does were fed on diets before mating for 4 weeks. Then, each doe showing the signs of receptivity was taken to the buck's cage for mating and, then returned back to its cage after being bred. Mating was assured after 2 successful trials and the day of mating was designated at first day of pregnancy, All mated does were palpated 14 days post mating to determine pregnancy or to repeat mating in case of pregnancy failure. Five days before kindling, does were provided with an access to nest boxes that were attached to each cage, and supplied with rice straw to provide a comfortable and warm place for kindling and rearing of bunnies. Once bunnies were observed for the first time inside the nest box, they were examined, counted and weighed to obtain the total litter size and litter weight at birth for each doe, then kits were weighed at the day of weaning (the $30^{\text {th }}$ day). Kit's mortality rate was recorded for each group from birth till weaning. Does were weighed individually at the start of the experiment and just at mating and at half of pregnancy period. These does were used for three consecutive parities. An experimental balanced pelleted ration was used ad libitum according to the reproductive state of animals. Does were fed experimental diet to cover their requirements according to Agriculture Ministry Decree (1996) recommendations.

\section{Sampling and analysis}

The formulation and chemical composition of the basal experimental diet are shown in Table (1). Chemical analyses of diet was determined according to AOAC (2005). 
Table (1): Formulation and chemical analysis of the experimental diet.

\begin{tabular}{lc}
\hline Item & Content, $\%$ \\
\hline Clover hay (12\%CP) & 20.08 \\
Yellow corn & 24.85 \\
Soybean meal (44\%CP) & 21.30 \\
Wheat bran & 26.90 \\
Molasses & 3.00 \\
DL-Methionine & 0.11 \\
${ }^{*}$ Vit. \& Min. mixture & 0.30 \\
NaCl & 0.50 \\
Limestone & 1.05 \\
Di-Calcium Phosphate & 1.91 \\
Chemical analysis ${ }^{1}$ & Content \\
Crude protein, \% & 18.03 \\
Ether extract, \% & 2.80 \\
Crude fiber, \% & 11.11 \\
NDF, $\%$ & 36.22 \\
ADF, $\%$ & 19.56 \\
Hemicellulose ${ }^{2} \%$ & 16.66 \\
Calcium \% & 1.22 \\
Total Phosphorus, \% & 0.81 \\
Methionine, \% & 0.36 \\
TSAA & 0.65 \\
Lysine, \% & 0.86 \\
**Digestible energy Kcal/Kg & 2603 \\
C/P ratio & 144 \\
\hline
\end{tabular}

* provided per $1 \mathrm{~kg}$ diet: $6000 \mathrm{IU}$ vit. $\mathrm{A} ; 900 \mathrm{IU}$, vit. $\mathrm{D}_{3} ; 40 \mathrm{mg}$, vit. $\mathrm{E} ; 2.0 \mathrm{mg}$, vit. $\mathrm{K}_{3} ; 2.0 \mathrm{mg}$ vit., $B_{1} ; 4.0 \mathrm{mg}$, vit. $B_{2} ; 2.0 \mathrm{mg}$, vit. $B_{6} ; 0.010 \mathrm{mg}$ vit. $B_{12} ; 10.0 \mathrm{mg}$ vit, $B_{5} ; 0.05 \mathrm{mg} B_{8} ; 3.0 \mathrm{mg} \mathrm{B} B_{9} ; 250 \mathrm{mg}$ choline; $50.0 \mathrm{mg} \mathrm{Fe} ; 50.0$ $\mathrm{mg} \mathrm{Zn;} 8.5 \mathrm{mg} \mathrm{Mn;} 5.0 \mathrm{mg} \mathrm{Cu} ; 0.20 \mathrm{mg}$ I, and $0.01 \mathrm{mg} \mathrm{Se}$.

${ }^{1}$ according to Feed composition for animal and poultry feed stuff used in Egypt $\left(2001 .{ }^{2}\right.$ Hemicellulose $=\%$ NDF $-\%$ $\mathrm{ADF}$.

\section{Milk yield and chemical composition}

Milk yield for each doe was recorded at 7, 14, 21 and 28 days of lactation. For doing this bunnies were separated from their dams at $8.00 \mathrm{pm}$; thereafter the bunnies were allowed to suckle at 8.00 am in the next day. Milk production was calculated as the average of the differences between weight of each doe and their bunnies before and after suckling (weight-suckling-weight method) as described by (Davies et al. ,1964 and Zarrowe et al.,1965) .Milk samples $(10 \mathrm{ml})$ were collected from each does on day $21 \mathrm{using}$ "home made air vacuum pump" from nipples of mammary gland. Milk were analyzed according to methods of AOAC (2005).

\section{Digestibility trail}

Digestibility trail was carried out to determine the digestion coefficients and nutritive value using three rabbits from each treatment. Feces were collected daily, weighed and dried at $60^{\circ} \mathrm{C}$ for $48 \mathrm{hrs}$, finely ground and stored for chemical analysis. Data of quantities and chemical analysis of feed and feces were used to calculate the nutrients digestion coefficients and the nutritive values of the dietary treatments, as described by Cheeke et al. (1982). The samples of feed and feces were chemically analysis according to AOAC (2005). Neutral detergent fiber (NDF), Acid detergent fiber (ADF) and Detergent lignin (ADL) were determined by method of Van Socest (1982). 


\section{Blood parameters:}

Individual blood samples were taken at 9.00 am from the marginal ear vein and collected in $5 \mathrm{ml}$ from three does of each group in heparinized test tubes and centrifuged at 3000 r.p.m for 20 minutes, then plasma were transferred and stored in deep freezer at approximately $-20^{\circ} \mathrm{C}$ till the time for determine total lipids (Zollner and Kirsch, 1962), creatinine (Schirmeister, 1964), urea (Fawcett and Scott, 1960), total protein (Gornal et al., 1949), albumin (Doumas and Waston 1971), transaminase (AST, aspartate aminotransferase, ALT alanine aminotransferase, HDL, LDL and Triglyceride (Reitman and Frankle, 1957). Fresh blood samples were taken after collection for determine blood pictures including, red blood cells count (RBCs, / $\left(10^{3} / \mu \mathrm{l}\right)$. White blood cells count (WBCs, $\left(10^{3} / \mu \mathrm{l}\right)$, hemoglobin $(\mathrm{Hb}, \mathrm{g} / \mathrm{dl})$, hematocrit $(\mathrm{PCV})$, mean corpuscular volume $(\mathrm{MCV})$, mean corpuscular haemoglobin $(\mathrm{MCH})$, mean corpuscular haemoglobin concentration $(\mathrm{MCHC})$ and Platelet count $\left(10^{3} / \mu \mathrm{l}\right)$ according to Drew et al. (2004).

\section{Economic efficiency (EEF):}

The percentage of economic efficiency (EEF) was calculated according to price marketing during 2017.

\section{Statistical Analysis:}

Data of different parameters were statistically analyzed using SAS (2001), to determine variables differences between groups, statistical significant effects were further analyzed and means were compared using Duncan's Multiple Range tests (Duncan, 1955) to detect significant differences between means.

Kindling rate and pre-weaning mortality were compared within and between each treatment groups and parturition order by chi square analysis. The statistical model used was:

Yijk $=\mu+\mathrm{Ti}+$ Eijk

where:

Yijk $=$ the observation $\mu=$ Overall mean

$\mathrm{Ti}=$ Treatments

Eijk $=$ Experimental error, associated with $\mathrm{i}, \mathrm{j}$ and $\mathrm{k}$ observations assumed to be randomly distributed

\section{RESULTS AND DISCUSSION}

\section{Reproductive performance}

Reproductive performance of rabbit does and offspring are presented in Table (2). All traits (conception rate, litter size at birth, litter size at weaning, litter weight at birth and litter weight at weaning), except kit's mortality rate were significantly $(\mathrm{P}<0.05)$ affected by experimental treatments, where rabbits fed diets supplemented with aqueous vitex extract ( 5 or $7.5 \mathrm{~g} / \mathrm{kg}$ ) followed by the alcoholic extract gave the higher values compered to the control. These results may be due to the positive effect of vitex on hypophysis, which is progesteronic-like and may decrease extra level of prolactin (Azarnia et al., 2007). The vitex components crosses the placenta and enters fetal tissues, and increase the fetus growth or due to the balancing effect of vitex on hormone production, and to increase luteinizing hormone (LH) levels (Schellenberg, 2001).

Table (2): Effect of the experimental treatments on reproductive performance of rabbit does.

\begin{tabular}{|c|c|c|c|c|c|}
\hline \multirow{3}{*}{ Parameter } & \multicolumn{5}{|c|}{ Treatments } \\
\hline & \multirow[b]{2}{*}{ Control } & \multicolumn{2}{|c|}{ aqueous extract } & \multicolumn{2}{|c|}{ alcoholic extract } \\
\hline & & $5 \mathrm{~g} / \mathrm{kg}$ & $7.5 \mathrm{~g} / \mathrm{kg}$ & $5 \mathrm{~g} / \mathrm{kg}$ & $7.5 \mathrm{~g} / \mathrm{kg}$ \\
\hline Conception rate $\%$ & $71.50^{b} \pm 6.74$ & $88.00^{\mathrm{a}} \pm 5.33$ & $96.00^{\mathrm{a}} \pm 4.42$ & $92.00^{\mathrm{a}} \pm 2.66$ & $81.00^{\mathrm{ab}} \pm 6.83$ \\
\hline $\begin{array}{l}\text { Litter size at birth } \\
\text { (no) }\end{array}$ & $5.96^{\mathrm{b}} \pm 0.30$ & $7.06^{\mathrm{a}} \pm 0.34$ & $7.16^{\mathrm{a}} \pm 0.28$ & $6.73^{\mathrm{ab}} \pm 0.32$ & $6.80^{\mathrm{ab}} \pm 0.42$ \\
\hline Kit's mortality rate $\%$ & $1.51 \pm 0.86$ & $1.40 \pm 0.79$ & $3.61 \pm 1.72$ & $2.58 \pm 1.79$ & $4.23 \pm 3.36$ \\
\hline $\begin{array}{l}\text { Litter size at weaning } \\
\text { (no) }\end{array}$ & $5.86^{\mathrm{b}} \pm 0.28$ & $6.96^{\mathrm{a}} \pm 0.31$ & $6.93^{\mathrm{a}} \pm 0.30$ & $6.56^{\mathrm{ab}} \pm 0.27$ & $6.56^{\mathrm{ab}} \pm 0.38$ \\
\hline $\begin{array}{l}\text { Litter weight at birth } \\
\text { (g) }\end{array}$ & $283.00^{\mathrm{b}} \pm 12.1$ & $324.33^{\mathrm{a}} \pm 13.88$ & $331.3^{\mathrm{a}} \pm 12.4$ & $312.0^{\mathrm{ab}} \pm 14.08$ & $321.66^{\mathrm{ab}} \pm 14.72$ \\
\hline weaning $(\mathrm{g})$ & $2731.7^{\mathrm{b}} \pm 125$ & $3155.00^{\mathrm{a}} \pm 135.0$ & $3268.3^{\mathrm{a}} \pm 129.2$ & $2990.0^{\mathrm{ab}} \pm 130.4$ & $3086.7^{\mathrm{ab}} \pm 150.6$ \\
\hline
\end{tabular}




\section{Milk yield}

It is evident from obtained results that milk yield was gradually increased by increasing age of the suckling kits reaching the peak at the third week, then decreased thereafter during the fourth week.

Milk yield of does fed the diet with $7.5 \mathrm{~g}$ aqueous extract of vitex leaves significantly $(\mathrm{P}<0.05)$ higher than other treatments including control group that show the lowest milk yield (Table 3). These result may be due to that vitex works on the pituitary gland and hypothalamus by helping to increase the production of a lutene hormone. In addition, it also aids in the inhibition of the release of FSH, a follicle-stimulating hormone. This helps balance out the ratio of progesterone to estrogen so the vitex can helps to balance and produce hormones that are vital to milk production. So This herb is believed to help stimulate lactation (Loch et al., 2000).

Table (3 ): Effect of the experimental treatments on Mmilk yield (g/day) of rabbit does.

\begin{tabular}{|c|c|c|c|c|c|}
\hline \multirow{3}{*}{$\begin{array}{l}\text { Suckling } \\
\text { period } \\
\text { (day) }\end{array}$} & \multicolumn{5}{|c|}{ Treatments } \\
\hline & \multirow{2}{*}{$\begin{array}{c}\text { Control } \\
\text { diet }\end{array}$} & \multicolumn{2}{|c|}{ aqueous extract } & \multicolumn{2}{|c|}{ alcoholic extract } \\
\hline & & $5 \mathrm{~g} / \mathrm{kg}$ & $7.5 \mathrm{~g} / \mathrm{kg}$ & $5 \mathrm{~g} / \mathrm{kg}$ & $7.5 \mathrm{~g} / \mathrm{kg}$ \\
\hline & $59.00^{c} \pm 4.33$ & $61.33^{b c} \pm 3.34$ & $94.16^{\mathrm{a}} \pm 2.76$ & $69.83^{b} \pm 2.45$ & $69.50^{b} \pm 3.36$ \\
\hline 1 & $98.66^{\mathrm{c}} \pm 4.55$ & $103.16^{\mathrm{c}} \pm 4.57$ & $141.00^{\mathrm{a}} \pm 5.99$ & $123.16^{\mathrm{b}} \pm 3.32$ & $111.50^{b c} \pm 3.54$ \\
\hline 14 & $130.50^{c} \pm 5.25$ & $144.00^{\mathrm{bc}} \pm 8.59$ & $182.00^{\mathrm{a}} \pm 5.64$ & $158.66^{\mathrm{b}} \pm 4.03$ & $151.66^{\mathrm{b}} \pm 4.96$ \\
\hline $\begin{array}{l}21 \\
28\end{array}$ & $76.66^{\mathrm{d}} \pm 2.54$ & $81.16^{\mathrm{c}} \pm 2.32$ & $98.50^{\mathrm{a}} \pm 3.09$ & $90.83^{b} \pm 2.386$ & $86.66^{c} \pm 2.51$ \\
\hline
\end{tabular}

$a, b, c, d$ : Values in the same row with different superscripts are significantly differ at $P<0.05$.

\section{Milk Composition}

Does which having $7.5 \mathrm{~g}$ alcoholic extract of vitex leaves showed significantly $(\mathrm{P}<0.05)$ increase in dry matter, protein, lactose and minerals than other treatments (Table 4). These result may be due to that vitex extract can have a significant effect on blood parameters, and there were no significantly effect on fat. Rabbit milk composition varies depending on various factors; breed, nutrition, lactation stage , and number of pups (Lukafahr et al., 1983 and Chrastinova et al., 1997). The exact mechanism of flavonoid effect on cholesterol and proteins is still not clear (Anderson, 1995and James and Anderson, 1994).

Table (4): Effect of the experimental treatments on milk compostion (g) of rabbit does.

\begin{tabular}{|c|c|c|c|c|c|}
\hline \multirow{3}{*}{$\begin{array}{l}\text { Milk } \\
\text { analysis }\end{array}$} & \multicolumn{5}{|c|}{ Treatments } \\
\hline & \multirow[t]{2}{*}{ Control } & \multicolumn{2}{|c|}{ aqueous extract } & \multicolumn{2}{|c|}{ alcoholic extract } \\
\hline & & $5 \mathrm{~g} / \mathrm{kg}$ & $7.5 \mathrm{~g} / \mathrm{kg}$ & $5 \mathrm{~g} / \mathrm{kg}$ & $7.5 \mathrm{~g} / \mathrm{kg}$ \\
\hline Dry matter & $37.83^{c} \pm 0.07$ & $38.06^{b} \pm 0.13$ & $38.36^{\mathrm{ab}} \pm 0.13$ & $38.40^{\mathrm{ab}} \pm 0.16$ & $38.71^{\mathrm{a}} \pm 0.17$ \\
\hline Protein & $15.46^{\mathrm{ab}} \pm 0.10$ & $15.17^{\mathrm{b}} \pm 0.11$ & $15.40^{\mathrm{ab}} \pm 0.07$ & $15.40^{\mathrm{ab}} \pm 0.02$ & $15.55^{\mathrm{a}} \pm 0.03$ \\
\hline Fat & $16.45 \pm 0.23$ & $16.67 \pm 0.11$ & $16.78 \pm 0.14$ & $16.73 \pm 0.14$ & $16.83 \pm 0.04$ \\
\hline Lactose & $3.23^{\mathrm{b}} \pm 0.04$ & $3.33^{\mathrm{b}} \pm 0.06$ & $3.50^{\mathrm{a}} \pm 0.03$ & $3.55^{\mathrm{a}} \pm 0.03$ & $3.53^{\mathrm{a}} \pm 0.04$ \\
\hline Ash & $2.53^{\mathrm{b}} \pm 0.06$ & $2.80^{\mathrm{ab}} \pm 0.06$ & $2.68^{\mathrm{ab}} \pm 0.08$ & $2.71^{\mathrm{ab}} \pm 0.11$ & $2.83^{\mathrm{a}} \pm 0.09$ \\
\hline
\end{tabular}

$a, b, c$ : Values in the same row with different superscripts are significantly differ at $P<0.05$

\section{Body weight of does}

The results in Table (5) show that body weight of does were significantly influenced $(\mathrm{P}<0.05)$ by adding vitex, and the control group showed lowest body weight at mating and at half of pregnancy period than other groups $(3.250$ and $3.575 \mathrm{~kg}$ ), respectively. The enhancing in body weight might attributed to the nutrient of vitex extracts might which have allowed proper utilization of the nutrients in the normal level, this result agreed with Akhondzadeh (2000). 
Table (5 ): Effect of the experimental treatments on body weight (g) of rabbit does.

\begin{tabular}{|c|c|c|c|c|c|}
\hline \multirow[t]{3}{*}{ Weight of does (kg) } & \multicolumn{5}{|c|}{ Treatments } \\
\hline & \multirow[t]{2}{*}{ Control } & \multicolumn{2}{|c|}{ aqueous extract } & \multicolumn{2}{|c|}{ alcoholic extract } \\
\hline & & $5 \mathrm{~g} / \mathrm{kg}$ & $7.5 \mathrm{~g} / \mathrm{kg}$ & $5 \mathrm{~g} / \mathrm{kg}$ & $7.5 \mathrm{~g} / \mathrm{kg}$ \\
\hline At starting & $3.13 \pm 0.05$ & $3.15 \pm 0.04$ & $3.22 \pm 0.06$ & $3.21 \pm 0.057$ & $3.20 \pm 0.05$ \\
\hline At mating & $3.25^{\mathrm{b}} \pm 0.06$ & $3.36^{\mathrm{ab}} \pm 0.06$ & $3.56^{\mathrm{a}} \pm 0.06$ & $3.46^{\mathrm{ab}} \pm 0.11$ & $3.40^{\mathrm{ab}} \pm 0.111$ \\
\hline $\begin{array}{l}\text { At half of pregnancy } \\
\text { period }\end{array}$ & $3.58^{\mathrm{b}} \pm 0.06$ & $3.78^{\mathrm{ab}} \pm 0.11$ & $4.10^{\mathrm{a}} \pm 0.11$ & $3.95^{\mathrm{ab}} \pm 0.18$ & $3.81^{\mathrm{ab}} \pm 0.15$ \\
\hline
\end{tabular}

$a, b$ : Values in the same row with different superscripts are significantly differ at $P<0.05$

\section{Feed intake}

The following figure (Figure1) shows that feed intake was increased gradually as the age increase, and the result showed significantly decrease $(\mathrm{P}<0.05)$ in feed intake of does reared under control group than other groups having vitex extract. The significantly $(\mathrm{P}<0.05)$ increase in feed intake of vitex groups may be due to the positive impact on feed conversion ratio (Berrin etal., 2016). Also Nath et al. (2012) indicated that vitex in the broiler rations may be useful and could be used as an alternative growth promoters.

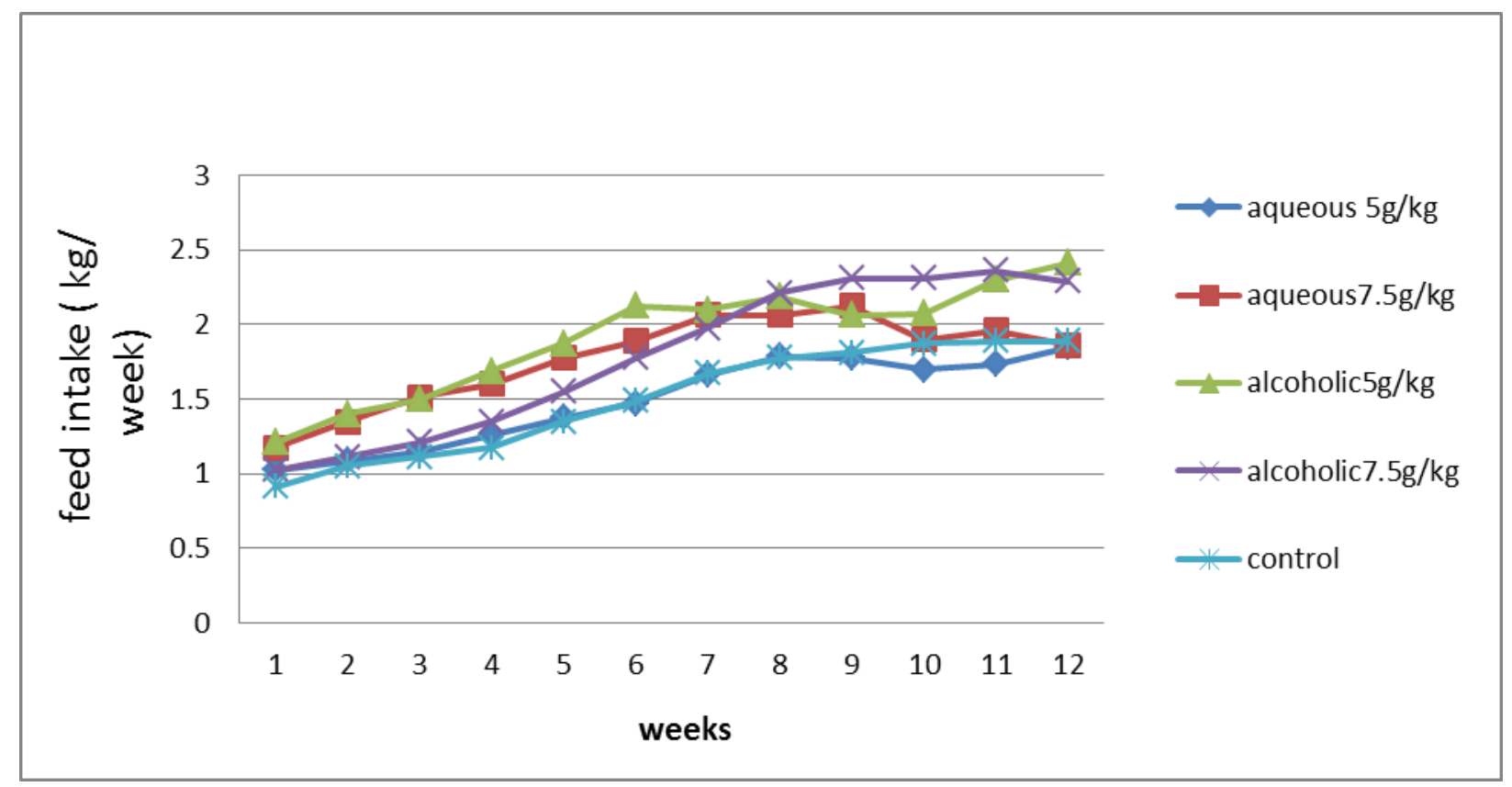

Figure (1): Effect of the experimental treatments on feed intake (g) of rabbit does.

\section{Digestion coefficients of nutrients and nutritive values.}

Data tabulated in Table (6) indicate that values of all nutrients digestion coefficients, except NFE and nutritive values as DCP were significantly $(\mathrm{P} \leq 0.05)$ improved with dietary treatments, especially with using aqueous extract. And the best value was reported for $7.5 \mathrm{~g} / \mathrm{kg}$ aqueous extract.

The positive effect of vitex extracts on digestion coefficients of different nutrients and nutritive values may be due to antimicrobial and anti-protozoal properties of compounds in vitex extract which promotes gastrointestinal health (Kale et. al., 2003 and Bishnu et al., 2009) which improved the feed consumption 
and feed efficiency for animals. Also, results are agreed with those reported by Siddig and Abdelati (2001) who carried out a research work in broiler fed rations containing turmeric and cloves showing higher weight gain. The improvement in growth performance using cinnamon rations may probably be due to the fact that cinnamon extract inhibits growth of intestinal bacteria such as S. aureus and E. coli as reported by Hanafy and Hatam (1991). Resultantly, when the load of these bacteria in the intestine is low, birds may absorb more nutrients, thus leading to improve the digestion coefficients and Nutritive values of the birds using rations supplemented with turmeric and cloves.

Table (6): Effect of the experimental treatments on digestion coefficients of nutrients (\%) and nutritive values.

\begin{tabular}{|c|c|c|c|c|c|c|c|c|c|}
\hline \multicolumn{2}{|c|}{ Treatments } & \multicolumn{6}{|c|}{ Digestion coefficients $(\%)$} & \multicolumn{2}{|c|}{ Nutritive values } \\
\hline & & DM & $\mathrm{OM}$ & $\mathrm{CP}$ & $\mathrm{CF}$ & $\mathrm{EE}$ & NFE & TDN & DCP \\
\hline \multirow{2}{*}{\multicolumn{2}{|c|}{ Control diet }} & $64.31^{\mathrm{b}}$ & $60.21^{b}$ & $72.01^{\mathrm{c}}$ & $49.43^{\mathrm{c}}$ & $81.62^{\mathrm{c}}$ & 77.24 & 69.79 & $12.90^{\mathrm{c}}$ \\
\hline & & \pm 0.95 & \pm 0.17 & \pm 0.84 & \pm 1.57 & \pm 0.58 & \pm 1.79 & \pm 2.00 & \pm 0.15 \\
\hline \multirow[t]{4}{*}{$\begin{array}{l}\text { aqueous } \\
\text { extract }\end{array}$} & $5 \mathrm{~g} / \mathrm{kg}$ & $64.66^{\mathrm{b}}$ & $60.70^{\mathrm{b}}$ & $77.85^{b}$ & $52.31^{\mathrm{bc}}$ & $84.37^{\mathrm{b}}$ & 77.91 & 70.93 & $13.75^{b}$ \\
\hline & & \pm 0.53 & \pm 0.65 & \pm 0.67 & \pm 0.91 & \pm 0.52 & \pm 0.58 & \pm 0.59 & \pm 0.12 \\
\hline & $7.5 \mathrm{~g} / \mathrm{kg}$ & $67.24^{\mathrm{a}}$ & $63.47^{\mathrm{a}}$ & $80.84^{\mathrm{a}}$ & $53.32^{b}$ & $86.11^{\mathrm{a}}$ & 78.90 & 69.57 & $14.37^{\mathrm{a}}$ \\
\hline & & \pm 0.42 & \pm 0.69 & \pm 0.30 & \pm 0.81 & \pm 0.04 & \pm 0.39 & \pm 0.60 & \pm 0.05 \\
\hline \multirow[t]{4}{*}{$\begin{array}{l}\text { alcoholic } \\
\text { extract }\end{array}$} & $5 \mathrm{~g} / \mathrm{kg}$ & $68.72^{a}$ & $64.82^{\mathrm{a}}$ & $77.54^{b}$ & $56.91^{\mathrm{a}}$ & $83.13^{b c}$ & 78.23 & 69.90 & $13.78^{\mathrm{b}}$ \\
\hline & & \pm 0.56 & \pm 1.35 & \pm 0.95 & \pm 0.32 & \pm 0.75 & \pm 0.56 & \pm 0.54 & \pm 0.17 \\
\hline & $7.5 \mathrm{~g} / \mathrm{kg}$ & $67.89^{\mathrm{a}}$ & $64.16^{\mathrm{a}}$ & $78.23^{b}$ & $53.34^{\mathrm{b}}$ & $84.70^{\mathrm{ab}}$ & 76.80 & 69.33 & $13.98^{\mathrm{b}}$ \\
\hline & & \pm 0.28 & \pm 0.35 & \pm 0.43 & \pm 0.33 & \pm 0.32 & \pm 1.57 & \pm 0.91 & \pm 0.07 \\
\hline
\end{tabular}

$a, b, c:$ Values in the same column with different superscripts are significantly differ at $P<0.05$.

\section{Blood parameters}

Results of blood constituents (Table 7) show that there wasn't significant effect of experimental treatments on all traits, except total lipid and triglyceride were affected significantly $(\mathrm{P} \leq 0.05)$. That, the highest value for triglyceride was for $5 \mathrm{~g} / \mathrm{kg}$ aqueous extract $(80.09 \mathrm{mg} / \mathrm{dl})$ besides, the highest value for total lipid (mg/dl) was for $7.5 \mathrm{~g} / \mathrm{kg}$ alcoholic extract (352.26) whereas, the lowest value for total lipid was for $5 \mathrm{~g} / \mathrm{kg}$ aqueous extract $(344.09 \mathrm{mg} / \mathrm{dl})$ however the lowest value for triglyceride was for $5 \mathrm{~g} / \mathrm{kg}$ alcoholic extract (79.36) comparing with the values for control diet which were 351.90 and $80.02 \mathrm{mg} / \mathrm{dl}$ for total lipid and triglyceride respectively. In this turn, Mustafa (2007) reported that no changes were noticed in blood profile, and this may be due to the differences in the solvent that used in extraction. And pointed out that blood cholesterol levels were reduced by using a plant extract, this action may attributed to the existence of flavonoids. Flavonoids are known to regulate cholesterol production and exert a potent hypocholesterolemic effect via suppression of the 3-hydroxy-3-methyl-glutaryl-coenzyme A reductase (HMGCoA reductase enzyme). Also, Unlike statin drugs, which reduce the activity of the HMG-CoA reductase enzyme. Flavonoids appear to reduce total cholesterol levels by anovel posttranscriptional mechanism that regulates the degradation rate of the HMG-CoA reductase enzyme 
(Nawarskas, 2005).Other studies have demonstrated the antioxidant and anti-inflammatory benefits of flavonoids, and when combined with the current findings of a significant and repeatable reduction of total cholesterol and triglycerides, they lend further support to the overall cardio-protective benefits of these natural extracts (James et al., 2007).

Table (7): Effect of the experimental treatments on some blood constituents of rabbit does.

\begin{tabular}{|c|c|c|c|c|c|}
\hline \multirow[t]{3}{*}{ Parameter } & \multicolumn{5}{|c|}{ Experimental treatments } \\
\hline & \multirow{2}{*}{$\begin{array}{c}\text { Control } \\
\text { diet }\end{array}$} & \multicolumn{2}{|c|}{ aqueous extract } & \multicolumn{2}{|c|}{ alcoholic extract } \\
\hline & & $5 \mathrm{~g} / \mathrm{kg}$ & $7.5 \mathrm{~g} / \mathrm{kg}$ & $5 \mathrm{~g} / \mathrm{kg}$ & $7.5 \mathrm{~g} / \mathrm{kg}$ \\
\hline Total protein, $(\mathrm{g} / \mathrm{dl})$ & $5.55 \pm 0.10$ & $5.77 \pm 0.13$ & $5.84 \pm 0.09$ & $5.74 \pm 0.16$ & 5.810 .12 \\
\hline Albumin, (g/dl) & $4.43 \pm 0.08$ & $4.34 \pm 0.10$ & $4.35 \pm 0.14$ & $4.11 \pm 0.09$ & 4.360 .11 \\
\hline HDL (mg/dl) & $64.25 \pm 0.13$ & $64.59 \pm 0.19$ & $64.31 \pm 0.16$ & $64.18 \pm 0.11$ & $64.67 \pm 0.13$ \\
\hline $\mathrm{LDL}(\mathrm{mg} / \mathrm{dl})$ & $135.11 \pm 0.07$ & $135.04 \pm 0.11$ & $135.15 \pm 0.09$ & $135.24 \pm 0.05$ & $135.26 \pm 0.12$ \\
\hline Total lipid (mg/dl) & $351.90^{\mathrm{a}} \pm 1.05$ & $344.09^{c} \pm 1.2$ & $347.52^{\mathrm{b}} \pm 1.3$ & $349.40^{\mathrm{ab}} \pm 1.22$ & $352.26^{\mathrm{a}} \pm 1.09$ \\
\hline Triglyceride (mg/dl) & $80.02^{\mathrm{ab}} \pm 0.13$ & $80.09^{\mathrm{a}} \pm 0.22$ & $79.82^{\mathrm{ab}} \pm 0.2$ & $79.36^{\mathrm{c}} \pm 0.24$ & $79.61^{\mathrm{bc}} \pm 0.19$ \\
\hline Urea-N,( mg/dl) & $47.38 \pm 0.40$ & $47.33 \pm 0.43$ & $47.30 \pm 0.48$ & $47.07 \pm 0.50$ & $47.14 \pm 0.37$ \\
\hline Creatinine mg/dl & $0.656 \pm 0.01$ & $0.652 \pm 0.06$ & $0.645 \pm 0.03$ & $0.653 \pm 0.04$ & $0.654 \pm 0.08$ \\
\hline AST(U/L) & $46.18 \pm 0.17$ & $46.04 \pm 0.23$ & $46.37 \pm 0.11$ & $45.89 \pm 0.25$ & $45.91 \pm 0.33$ \\
\hline $\operatorname{ALT}(\mathrm{U} / \mathrm{L})$ & $57.42 \pm 0.14$ & $57.16 \pm 0.18$ & $57.59 \pm 0.13$ & 57.150 .23 & $57.21 \pm 0.15$ \\
\hline
\end{tabular}

ALT: alanine amiotransferase; AST: aspartate aminotransferase HDL: high density lipoproteinLDL: low density lipoprotein.

$a,, b$ and $c$ means in the same row with different superscripts are significantly different $(P \leq 0.05)$.

\section{Hematological parameters:}

Data listed in Table (8) show no significant effect of experimental treatments on all traits belong hematological parameters (haemoglobin, red blood cell, hematocrit (PCV), MCV, MCH, MCHC, platelet

Table (8): Effect of the experimental treatments on haematological parameters of rabbit does.

\begin{tabular}{|c|c|c|c|c|c|}
\hline \multirow[t]{3}{*}{ Parameter } & \multicolumn{5}{|c|}{ Experimental treatments } \\
\hline & \multirow{2}{*}{$\begin{array}{c}\text { Control } \\
\text { diet }\end{array}$} & \multicolumn{2}{|c|}{ aqueous extract } & \multicolumn{2}{|c|}{ alcoholic extract } \\
\hline & & $5 \mathrm{~g} / \mathrm{kg}$ & $7.5 \mathrm{~g} / \mathrm{kg}$ & $5 \mathrm{~g} / \mathrm{kg}$ & $7.5 \mathrm{~g} / \mathrm{kg}$ \\
\hline Haemoglobin $(\mathrm{g} / \mathrm{dl})$ & $13.38 \pm 0.25$ & $12.80 \pm 0.30$ & $12.99 \pm 0.26$ & $13.07 \pm 0.29$ & $13.60 \pm 0.32$ \\
\hline Red blood cell $\left(10^{6} / \mu \mathrm{l}\right)$ & $5.87 \pm 0.18$ & $5.57 \pm 0.22$ & $5.69 \pm 0.37$ & $5.59 \pm 0.20$ & $5.58 \pm 0.25$ \\
\hline Hematocrit\% (PCV) & 13.38 & 12.80 & 12.99 & 13.07 & 13.60 \\
\hline $\mathrm{MCV}^{(1)}(\mathrm{fl})$ & $45.63 \pm 0.23$ & $44.79 \pm 0.34$ & $45.25 \pm 0.37$ & $45.65 \pm 0.25$ & $45.58 \pm 0.28$ \\
\hline $\mathrm{MCH}^{(2)}(\mathrm{pg})$ & $23.03 \pm 0.28$ & $22.89 \pm 0.30$ & $22.80 \pm 0.38$ & $23.16 \pm 0.25$ & $23.57 \pm 0.33$ \\
\hline $\operatorname{MCHC}^{(3)}(\mathrm{g} / \mathrm{l})$ & $29.51 \pm 0.18$ & $29.79 \pm 0.20$ & $29.72 \pm 0.22$ & $29.71 \pm 0.30$ & $29.69 \pm 0.25$ \\
\hline Platelet count $\left(10^{3} / \mu \mathrm{l}\right)$ & $257.67 \pm 2.13$ & $258.01 \pm 2.38$ & $255.43 \pm 2.22$ & $256.26 \pm 2.27$ & $254.54 \pm 2.35$ \\
\hline White blood cell $\left(10^{3} / \mu \mathrm{l}\right)$ & $7.20 \pm 0.11$ & $6.90 \pm 0.15$ & $7.07 \pm 0.20$ & $6.93 \pm 0.18$ & $7.03 \pm 0.25$ \\
\hline
\end{tabular}

1:Mean corpuscular volume , 2: Mean corpuscular hemoglobin 3: Mean corpuscular hemoglobin concentration.

count and white cell count). These results agree with Mustafa (2007) who reported that vitex extract had no significant effect on white blood cells compared with the control group. The decrease in some blood parameters maybe due to the presence of flavonoids in this plant, it has been shown that the flavonoids can decrease the number of red blood cells and packed cell volume and hemoglobin (Wang and Tang , 1995 and Young et al., 1997). The essential oils of this plant can also affect blood parameters by inhibition of synthesis of red blood cells (Wang and Tang, 1995). Essential oils and flavonoids were also shown in another study to affect blood parameters resulting in decreased production of its elements (Blumenthal, 2000). 
Table (9). Phytochemical composition of aquatic and alcoholic extract of Vitex agnus-castus

\begin{tabular}{lcc}
\hline Phytochemical & Aquatic extract & Alcoholic extract \\
\hline Flavonoids & + & + \\
Saponins & + & + \\
Terpenoids & + & + \\
Anthraquinones & + & + \\
Cardiac glycosides & - & - \\
Alkaloids & + & + \\
Tannins & + & - \\
\hline
\end{tabular}

Phytochemical Screening in Table (9) showed that, alkaloids, saponins, tannins, anthraquinones, flavonoids and terpenoids were detected in aqueous extract. However, alkaloids, saponins, anthraquinones, flavonoids and terpenoids were detected in alcoholic extract. These results agree with Varadarajan et al. (2008) who reported that medicinal values of the plant leaves may be related to their constituent phytochemicals.

\section{Economical evaluation}

Data concerning economical evaluation are summarized in Table (10). The present results indicated an increase of net revenue for rabbits fed diets contained aqueous extract of vitex leaves at all levels compared to those fed alcoholic extract of vitex leaves and control diets, that the values of economic efficiency for 5 and $7.5 \mathrm{~g} / \mathrm{kg}$ aqueous extract were 38.89 and 30.23 respectively compared with 11.68 for control diet, this related to improving in weaning rabbit of aqueous extract groups with a low total feed cost comparing with control group. These results agree with Nath et al. (2012) who indicated that polyherbal supplementation like vitex in the broiler rations may be useful for the safe, economical and efficient production of broiler and this formulation could be used as an alternative to commercial growth promoters.

Table (10): Economical evaluaton for rabbit as affected by different dietary treatments.

\begin{tabular}{|c|c|c|c|c|c|}
\hline \multirow[t]{3}{*}{ Item } & \multicolumn{5}{|c|}{ Experimental treatments } \\
\hline & \multirow{2}{*}{$\begin{array}{c}\text { Control } \\
\text { diet }\end{array}$} & \multicolumn{2}{|c|}{ aqueous extract } & \multicolumn{2}{|c|}{ alcoholic extract } \\
\hline & & $5 \mathrm{~g} / \mathrm{kg}$ & $7.5 \mathrm{~g} / \mathrm{kg}$ & $5 \mathrm{~g} / \mathrm{kg}$ & $7.5 \mathrm{~g} / \mathrm{kg}$ \\
\hline $\begin{array}{l}\text { Total feed intake } \\
(\mathrm{kg})^{(1)}\end{array}$ & 18.98 & 17.84 & 19.18 & 21.96 & 21.46 \\
\hline Price diet/kg L.E & 4.25 & 4.27 & 4.32 & 4.30 & 4.35 \\
\hline Total feed cost (L.E.) & 80.67 & 76.18 & 82.86 & 94.43 & 93.35 \\
\hline $\begin{array}{l}\text { Weaning rabbit } \\
\text { produced }(\mathrm{kg} / \text { doe })\end{array}$ & 2.73 & 3.16 & 3.27 & 3.00 & 3.1 \\
\hline Selling price (L.E.) ${ }^{(2)}$ & 90.09 & 104.28 & 107.91 & 99 & 102.3 \\
\hline Net revenue (L.E.) ${ }^{(3)}$ & 9.42 & 28.10 & 25.05 & 4.57 & 8.95 \\
\hline $\begin{array}{l}\text { Economic efficiency } \\
\%^{(4)}\end{array}$ & 11.70 & 36.90 & 30.23 & 4.8 & 9.6 \\
\hline
\end{tabular}

\section{CONCLUSION}

Supplementation of aqueous vitex leaves extract with $7.5 \mathrm{~g} / \mathrm{kg}$ in the diet of rabbit does improved their reproductive and productive performance. 


\section{Abd El Ghany et al.}

\section{REFERENCES}

Agriculture Ministry Decree (1996). The standard properties for ingredients, feed additives and feed manufactured for animal and poultry. El-Wakaee El-Masria, Amirria Press Cairo, Egypt. No.192,95.

Akhondzadeh, Sh. (2000). Encyclopedia of Iranian Medicinal plants. Arjomand press. p.144

Anderson, J.W., B.M. Johnstone and M.E. Cook-Newell (1995): Meta-analysis of the effects of soy protein intake on serum lipids. New England journal of medicine. 333: 276-282.

AOAC (2005). Association of Official Analytical Chemists. Official methods of analysis. $18^{\text {th }}$ Ed., Washington, D C, USA.

Azarnia, M., Ejtemaei-mehr., A.Shakoor and Ansari. (2007). Effect of vitex agnus castus on mice fetus development . Actamedica Iranica. 45: no.4.

Berrin ,K. G., K.Yusuf, A., Eray , S.Savaş, B.Selma and K.Mahmut ( 2016). The Effect of Dietary Supplementation of Vitex agnus-castus and Vitamin Combinations on Performance and Carcass Traits in Heat Stressed Broilers World's Poultry Science Journal, 4(7): 130-137

Bishnu J Sunil L and Anju S (2009). Antibacterial Property of Different Medicinal Plants: Ocimum sanctum, Cinnamomum Zeylanicum, Xanthoxylum armatum and Origanum majorana. Kathmandu University Journal of Science, Engineering and Technology 5: 43-50.

Blumenthal, M. (2000). Herbal medicine. Publication of integrative medicine communication ; 23: 220230.

Brenda, E.L.S., (2005). The effect of flavonoids on thyroid function. American Botanical Council, Austin ,3: 501- 505.

Cheeke, P.P. (1987). Rabbit Feeding and Nutrition. Orlando: Academic Press, Inc. Harcourt, Brace, Jovanovich, Publishers.

Cheeke, P.R. (1982). Potential of rabbit production in tropical and subtropical agricultural system. J. Anim. Sci., 63:1581-1586.

Chrastinova, L., A. Sommer, J. Rafay and M. Svetlanska (1997) Avotan exploitation in rabbit nutrition II. Nutrient digestibility and lactation performance of does rabbit. J. Farm Anim. Sci., 30:80-86.

Christie, S.and A.F.Walker (1998): Vitex agnus-castus: a review of its traditional and modern therapeutic use. The European Journal of Herbal Medicine 3: 29-45.

Davies,S.S.,Widdowson E.M. and Mccance.R.A.(1964).The intake of milk and the retention of its constituents while the new born rabbit doubles its weight .Brit.J.Nut.,18:385-392.

Doumas, B.T. and W. Waston (1971). Albumin standards and measurement of plasma albumin with bromocresol green. Clin. Chem. Acta., 31: 87.

Drew, P.; C.R. Harles; B. Trevor and L. John (2004). Oxford Handbook of Clinical Haematology. $2^{\text {nd }}$ Ed. Oxford University Press, USA.

Duncan, D.B. (1955). Multiple range and multiple F. test. Biometrics, 11: 1-42.

Fawcett, J.K. and J. E. Scott (1960). Determination of urea. J. Clic. Path., 13: 156-159.

Gornal, A.G.; C.J. Bardawill and M.M. Divid (1949). Determination of plasma protein by means of the biurent reaction. J. Biol. Chem., 177: 751.

Harborne I. B.(1973). Phytochemical Methods: A Guide to Modern Techniques of Plant Analysis, Chapman and Hall, New York, NY, USA, 2nd edition

Hanafy M.S. and M.E. Hatam (1991). Studies on the anti-microbial activity of N. sativa seed (Black cumin). Journal of Ethnopharmacology ,34: 275-278.

Hayder, B. S. , A. A.Adeeb, S.M. Hussain, G. A. Jasim, B. J. Qasim and S. S. Al Rawi (2014). Acute Toxicity of Vitex agnus castus Methanol Extract. Int. J. Pharm. Sci. Rev. Res., 26(2): 123-128.

Hobbs, C. (1991). The chaste tree: Vitex agnus-castus. Pharmacy in History , 33 (1): 19-24. 
Hoberg, E. P., A. A. Kocan and L. G. Rickard. (2000). Gastrointestinal strongyles in wild ruminants. In W. Samuel, M. Pybus, and A. A. Kocan ,Parasitic diseases of wild mammals, pp. 193-227 .

Hoberg, E.; J.Orjala , B.Meier and O. Sticher (1999).Diterpe noids from the fruits of Vitex agnus-castus. Phytochemistry 52: 1555-1558.

James, W. and M.D. Anderson (1994). Flavonoids significantly decrease total cholesterol and reduced formation of oxidized (LDL). The nutrition report . 54: 3428- 3435

James, D.B. , O.A. Owolabi, , A.O. Oluloto , H. Mohammed and O.A. Muhammed (2011). Change in Organs Weight and Antioxidant Potential of Combined Effects of Aqueous Extracts of Phyllanthus amarus and Vitex doniana Stem Bark on Streptozotocin-Induced Dibetic Rats. Asian Journal Medical Sciences, 3(6): 237-242.

James, M. , C.N. Roza, Z. Xian-Liu and N. Guthrie (2007). Effect of citrus falvonoids and tocotrienols on serum cholesterol levels in hypercholesterolemic subject alternatives therapies. Asian Journal Medical Sciences ,13 (6)23-29.

Kale B P, M. A. Kothekar, H.P. Tayade, J.B. Jaju and M. Mateenuddin (2003). Effect of aqueous extract of Azadirachta indica leaves on hepatotoxicity induced by antitubercular drugs in rats. Indian Journal of Pharmacology, 35(3), 177-180.

Loch, E.G., H. Selle, , and N. Boblitz, (2000) . Treatment of premenstrual syndrome With a phytopharmaceutical formulation containing Vitex agnus-castus. Journal of Womens Health Gender Based Medicine , 9: 315-320.

Lucks, B.C. ,J. Sorensen and L.Veal (2002) . Vitex agnus-castus essential oil and menopausal balance: a self-care survey. Complement Ther Nurs Midwifery. 8:148-154.

Lukefahr, S., W. D. Hohenboken, P. R. Cheeke and N. M. Patton (1983). Characterization of straightbred and crossbred rabbits for milk production and associative traits. J. Anim. Sci., 57:1100-1107.

Meyer, E.A. (1993) . Monkspepper: Mönchspfeffer: Im Mittelalter beliebt, jetzt erforscht. Pharmazie , 26(138): 24-26.

Milewicz, A. E., H. Gejdel, K. Sworen, J. Sienkiewicz, T.T.Jedrzejak and H.Schmitz (1993) . Vitex agnus-castus extract in the treatment of luteal phase defects due to latent hyperprolactinemia. Results of a randomizedplacebocontrolleddoubleblindstudyArzneimittelforschung, ( 43) : 752-756.

Mohamed, A.H., T.F. Fatma, and A.A.S Mahgoup(2016). Influence of supplementation of some trace minerals in form of nanoparticles on productive and reproductive performance of rabbit. Egyptian $\mathrm{J}$. Nutrition and feeds, 19 (2): 325-335.

Mustafa A. H. (2007). Effect of vitex agnus-castus extract T on some physiological parameters of mice (MUS MUSCULUS L.). The medical journal of basrah university. MJBU, Vol 25, No.2, 2007

Nath, D. D. , M. M. Rahman, F. Akter and M. Mostofa (2012). Effects of Tulsi, Black Pepper and cloves extract as a growth promoter in broiler.Bangl. J. Vet. Med. , 10 (1\&2): 33-39 .

Nawarskas, J.J. (2005). HMG-CoA reductase inhibitors and coenzyme Q10, Cardiol Rev, 13(2): 76-79.

Odenthal, K.P. (1998). Vitex agnus-castus L.- traditional drug and actual indiations. Phytotherapy Research ,12: 160-161.

Reitman, S. and S. Frankel (1957). Determination of GOT and GPT Amr. J. Clin. Path., 28:56-63.

SAS (2001). SAS /STAT User’s Guide (Release 8.2). SAS Inst. Inc., Cary NC, USA.

Schellenberg, R. (2001): Treatment of premenstrual syndrome with vitex agnus-castus extract prospective. randomized, placebo controlled study. BMJ 20: 134-137.

Schirmeister, J. (1964). Determination of creatinine. Dtsch. Med Wschr., 89: 1940.

Siddig RM and Abdelati K (2001). Effect of dietary vitamin A and N. sativa on broiler chick's performance. In: Proc. of 10th Int. Conf. of Assoc. of Inst. for Trop. Vet. Med. Livestock. Community and Environment,Copenhegen, Denmark.

Trease G. E. and W. C. Evans (1983).Textbook of Pharmacognosy, Tindall, London, UK, 12th edition, 


\section{Abd El Ghany et al.}

Upton R, editor (2001). Bilberry Fruit Vaccinium myrtillus L. Standards of Analysis, Quality Control, and Therapeutics. Santa Cruz, CA: American Herbal Pharmacopoeia and Therapeutic Compendium;

Van Socest, P.J. (1982). Nutritional ecology of ruminant O and B Books.Inc., Corvallis, Oredon. 112: 126-127.

Varadarajan, P., G.Rathinaswamy, and D. Asirvatahm ( 2008 ). Antimicrobial properties and phytochemical constituents of Rheo discolor," Ethnobotanical Leaflet. 12: 841-845.

Wang JP, Tang CM (1995). Antiplatelet effect of Agrimonia pilosa.J. Chin Med (1995); 13(1-4): 109118.

Young JH, Hsu MF, Wang JP, Teng CM (1997). Effect of Agrimonia pilosa on experimental thrombosis in mice. J. Chin Med (1997); 15 (1-2): 43-51.

Zarrow,M.X.;V.K.DenebergandC.O.Anderson(1965).Rabbit:Frequencyof suckling in the pup .Science ,Washington,USA, 150:1835-1836.

Zollner, N. and K. Kirsch (1962). Determination of total lipids in blood by Colorimetric Method. Z. Ges. Exp. Med., 135: 454- 454.

تاثير كلا من المستخلص المائى والكحولى لنبات الفيتكس(كف مريم) على الاداء التناسلى و الانتاجى لامهات

فاطمة طلعت فرج عبدالغني 1 و ولاء حسين خليفة 2وعادل عحم محمد سبد أحمد 1

1معهد بحوث الإنتاج الحيوانى ـ مركز البحوث الزراعية ـ دقى - جيزة مصر

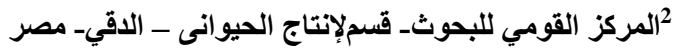

تهدف هدة الدراسة لمعرفة ناثير استخدام مستخلص نبات الفيتكس(كف مريم) على الاداء التناسلى والانتاجى للار انب تم استخدام

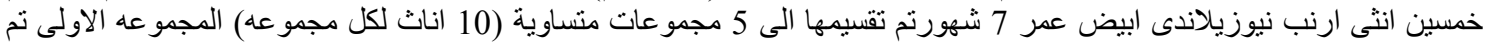

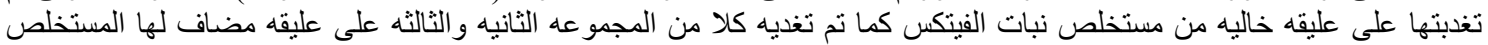

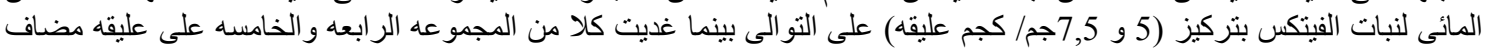

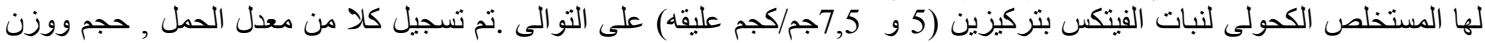

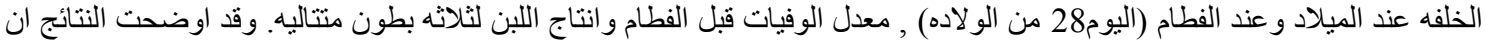

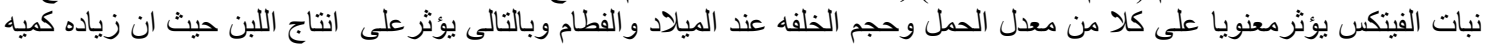

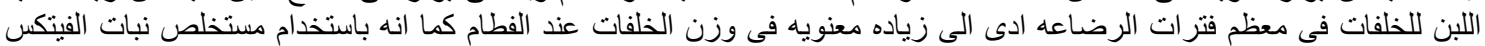

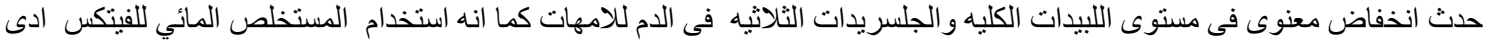

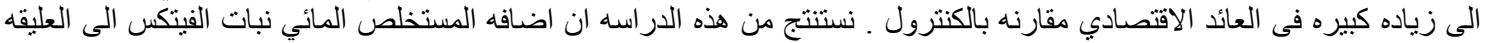

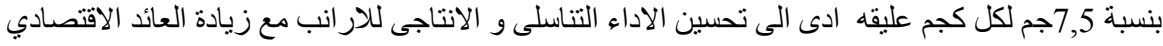

